\title{
Omani Young Children's Language Proficiencies: The Outcomes of a Bilingual Education Program
}

\author{
Ali Kemal Tekin \\ Assistant Professor, Department of Early Childhood Education, Sultan Qaboos University, Oman \\ Email: tekn@squ.edu.om
}

\section{Doi:10.5901/mjss.2014.v5n23p784}

\begin{abstract}
Due to a globalizing world context and contemporary trends in society, today's parents are more interested in having their children acquire English language skills as early as possible. In Oman, the movement to offer early childhood education in two languages-English and Arabic - has been accelerating. Through the efforts of Sultan Qaboos University, a model Child Care Center (CCC) was established on campus to pioneer bilingual education in the early years of life. This type of educational program also has the potential to impact young children's development and acquisition of their primary language. In addition, bilingual children's language usage outside the school in daily communications is another significant topic for study. However, there has been little solid research on this topic. Hence, this research study aimed to assess and evaluate English and primary language proficiency levels of young children enrolled at CCC and their language usage in communications outside the school environment. Implications are discussed and recommendations are made for teachers, parents, policy makers, researchers, and other stakeholders.
\end{abstract}

Keywords: bilingual education; bilingualism; early childhood education; EFL; Oman

\section{Introduction}

A member of the Gulf Cooperation Council (GCC), The Sultanate of Oman is a developing Arab country located in the southern part of the Arabian Peninsula with a population of 2,773,479, 1,957,336 of whom are Omani and 816,143, expatriates (National Center for Statistics and Information, 2010). Oman's main revenues come from oil and natural gas. Before 1970, only three formal schools existed in the whole country; today there are 1,052 public schools enrolling 563,236 students (Oman Cultural Office, n.d.). Once His Majesty, Sultan Qaboos bin Said, came into the power in 1970, he initiated an Education Renaissance that has led to great efforts to improve the education standards in the country. Yet while education costs total $24 \%$ of total government expenditures (UNICEF, 2008), several education variables, including preschool enrollment rate (8.25\%; UNICEF, 2008), are not at the desired levels. Significant attempts are being made to increase this enrollment rate. For example, the Omani government recently began to establish kindergarten classes attached to public elementary schools in order to include this period of education in the public system. This application is in its pilot phase.

Today's globalized world context and contemporary trends in almost all fields in society demand that individuals learn a foreign language, particularly English. English as a foreign language provides learners with open access to many domains of life, from education to technology, from culture to business, and so on. Since it is seen as an instrument that serves many purposes, English has received political, economic, and legislative support in Oman and has been central to the country's national development (Al-issa, 2006) since it is widely used in business, education, and the media (Albusaidi, 1995). Based on that fact, the Omani government adopted English as the official foreign language and allocated a budget and resources to its application in education (Al-issa \& Al-bulushi, 2012). In line with that notion, Omani parents have become more aware of the importance of learning English and hence more interested in having their children acquire English language skills as early as possible in order to connect to the world. They perceive English as a dominant foreign language locally and globally. This phenomenon has been rapidly absorbed by both public and private sectors and caused an accelerating movement to offer education in two languages: English and Arabic. Early childhood education in Oman has also been influenced by this bilingual education trend. However, the Omani public education system does not cover the early childhood period, comprehensively. While they are supervised by the Ministry of Social Development and Ministry of Education, bilingual early childhood education is managed by private institutions in Oman.

Amidst the debate about whether young children should receive education in a bilingual program or not, Sultan Qaboos University (SQU), the National University of the Sultanate of Oman, took the initiative and established in 2007 an 
on-campus Child Care Center (CCC) as a model to pioneer bilingual education in the early years of life. Principles and standards followed in this program are from the National Association for the Education of Young Children (NAEYC). Potentially, this type of educational program can have an impact on young children's development, specifically their language development in both Arabic, as language 1 (L1), and English, as language 2 (L2), as expected by all stakeholders. However, there has been little to no scientific research on the outcomes of such a bilingual program, and particularly on its basic motive, which is to influence young children's development of both languages. Hence, this research study aimed to investigate English and primary language proficiency levels of young children who are enrolled at CCC.

Further, young children, as interactive (Vygotsky, 1978) social agents functioning in society (Bronfenbrenner, 1979), are expected to accommodate and assimilate the knowledge and skills they have learned at school (Piaget, 1959) and transfer them to their daily lives. In this case, children in a bilingual education program are supposed to employ their newly acquired language knowledge and skills while connecting with the world outside the school, as well as when communicating with others. Although school, language, and community are interrelated with respect to language development and especially, bilingual education (Hornberger, 1988), there is no research evidence, particularly in the Omani context, on the employment and usage of English outside the school environment. This present study provides an in-depth look at whether young children enrolled in this program extend their English knowledge to non-educational contexts while communicating with the world surrounding them. The aims of this research were to: (1) investigate the language proficiencies of Omani young children currently enrolled at CCC, and (2) understand their L1 and L2 practice outside school in different contexts.

\section{Literature Review}

Researchers agree that early childhood is a critical period for language learning and development (e.g., Andersson, 1974; Nikolov, 2009), not only in L1 but also in L2 (Boyson, Semmer, Thompson, \& Rosenbusch, 2013), even in a situation of minimal exposure to L2 (Larson-Hall, 2008) since the basic process of language acquisition such as first words or first use of grammar (Bialystok, Craik, Green, \& Gollan, 2009) does not differ whether one or two languages are being acquired (Werker, 2012). It has been suggested that L2 education begin early in life since young children find it easier to pick up a new language (Nikolov 2009) than do adults. Exposure to a second language affects brain activity to language stimuli (Hidaka et al., 2012); young children have a wealth of placticity in their procedural memory (Paradis \& Kirova, 2014), sensory-motor experience-visual, and audial tactile. The resulting language learning potential to engage in bilingual education offers a significant opportunity to take full advantage of this situation (Andersson, 1974). Bilingual children claim to have separate linguistic systems for L1 and L2 (Du, 2010). Bilaystok (2009) said that young bilingual minds resembled an intriguing set of puzzles and argued that bilingual language acquisition would be efficient, effortless, and successful in the early stages of life compared to monolingual education. The idea for early bilingual education also has been supported by teachers (Habeeb, 2013; Pardington, 2007), parents (Al-jardani, 2012; Sturke, 2003), and government bodies (Al-issa, 2006; Lacina, Levine, \& Patience, 2010).

Current research studies support the belief that bilingualism in the early years should not be a source of concern for L1 acquisition (Bae, 2007). In this regard, the interaction and comparison between L1 and L2 have also been documented by researchers (e.g., Kan, 2014; Nikolov \& Csapo, 2010). For example, a case study conducted by Dastgahian and Rostami (2013) showed that early bilingualism did not cause any delay in language acquisition process. Although it is accepted that L1 knowledge is usually stronger than L2 among preschoolers (Sevinc \& Onkol, 2009; Unsworth, 2013), especially in vocabulary (Klassert, Gagarina, \& Kauschke, 2014) since, for example, some image representations are more strongly connected to L1 than L2 (Jared, Poh, \& Paivio, 2013), similarity has been found in rates and types of language processes such as phonology (Lin \& Johnson, 2010) and ability to repair conversational breakdowns (Comeau, Genesee, \& Mendelson, 2010). It also has been shown that bilingual children have the opportunity to assimilate new L2 sounds by matching them with familiar sounds in their L1, supporting the propositions of the Perceptual Assimilation Model (Ho, 2009). It can be claimed that stronger knowledge of L1 helps better acquisition of L2 (Yeung \& Chan, 2012). Hence, these research studies have shown that it is more efficient to implement a bilingual early childhood education program rather than a program solely conducted in L1 or L2 as bilingualism does not interfere with the language development of bilinguals (Comeau et al., 2010).

Besides, current research studies (e.g., Lopez \& Tashakkori, 2004) have revealed numerous benefits of bilingualism and early bilingual education experience in many aspects of children's development, including academic, cognitive, social, behavioral, and even physical. To be more specific, positive effects of early bilingual education on children's development have been documented in their literacy skills such as reading, writing and spelling (Lopez \& 
Tashakkori, 2004; Sun, Zhou, \& Zhu, 2013), English (Francis, Lesaux, \& August, 2006), math skills (Bialystok et al., 2009; Marian, Shook, \& Schroeder, 2013), metalinguistic competence (Lengyel, 2012) and awareness (Barac \& Bialystok, 2011; Reder, Marec-Breton, Gombert, \& Demont, 2013), focusing (Poulin-Dubois, Blaye, Coutya, \& Bialystok, 2011), remembering (Bialystok et al., 2009) , planning (Paradis, Geneese, \& Crago, 2011), ability to make decisions (Bialystok et al., 2009), problem-solving skills, speed of attention processing, inverse processing efficiency, independence of possible speed-accuracy trade-offs, network of executive control for conflict resolution (Yang, Yang, \& Lust, 2011), attention, control, working memory, abstract and symbolic representation skills (Adesope, Lavin, Thompson, \& Underleider, 2010), flexibility and complexity of brain activity (Zelasko \& Antunez, 2000), creativity (Leikin, 2013), attitudes towards English (Cepik), sociopragmatic awareness of English that involves request strategies rather than reply strategies (Zhang \& Yan, 2012), foreign language accent (Gilakjani \& Ahmadi, 2011; Piske, Mackay, \& Flege, 2001), identity development (Zelasko \& Antunez, 2000), communication skills in a diverse society, and the ability to free themselves from biases and limited thinking (Keysar, Hayakawa, \& An, 2011). There are also other potential benefits for their future, from school readiness to more job opportunities (Zelasko \& Antunez, 2000). Bilingualism may even delay the onset of Alzheimer's disease (Dreifus, 2011).

Since the focal languages in this study were Arabic and English, it was essential to look at research studies on bilingual education that involved these two languages. Unfortunately, there is no adequate research on this topic. Noting the limitation in the literature review for this study, the studies of Hussien (2014a, 2014b) should be mentioned. Hussien examined the language performance of bilingual children in both Arabic and English and concluded that they performed better than their monolingual counterparts (2014a) and that learning English has a positive effect on their Arabic skills (2014b). Due to the scarcity of sufficient research in the field, the present study aimed to investigate the language proficiencies of Omani young children currently enrolled at CCC who receive bilingual education in Arabic and English.

Moreover, since children are active agents in social life, a better understanding of their language usage while communicating with the world around them was the second aim of this study. Children's exposure to and usage of their two languages play significant roles in their language development (Hammer et al., 2012). A scientific inquiry into an early bilingual education program's outcomes should not be limited to only the school environment-it is also important to understand the child's usage of their two languages in different daily life contexts outside the school. The related literature shows that children's experience of their bilingualism outside the institution is useful and enriching in enabling them to make this knowledge an integral and important part of their daily life experiences (Lengyel, 2012). Thus, the social and communicative circumstances of language usage are an important aspect of studies of the bilingual child's language development (Lengyel, 2012) since dialogue and social interaction build linguistics knowledge (Lee, year). Several research studies have focused on bilingual children's language usage inside (Patterson) and outside (e.g., Dastghahian \& Rostami, 2013) the classroom setting. However, no research, to the author's knowledge, specifically investigated young bilingual children's usage of Arabic and English while communicating with other agents of society such as siblings and family in different daily life contexts outside the school.

\section{Research Methodology}

\subsection{Participants}

Study participants included 11 KG2 students enrolled at CCC/Sultan Qaboos University and their parents. KG1 students in the same educational setting were excluded because they had not been taught in a bilingual setting for more than a semester. Thus, in this research, only the KG2 students who had received a bilingual education for more than a semester in the same educational institution were included in the study because they would provide more concrete and solid data. In fact, there were 18 students in KG2 at CCC. However, only 11 (61\%) students responded to the study; the rest 7 (39\%) of the target population did not want to participate in the study (participation was voluntary). Their parents were also included as participants.

\subsection{Instrument}

Two instruments were employed in this study. The language survey included items to gather information on young children about their English and primary language skills. This survey was adapted from the "English and Primary Language Screening Tool" originally developed and used in the U.S. The researcher went through the necessary validation steps to adapt items to the Omani context, including use of an academic expert panel from the field of early childhood and translation procedures that included back-translation overseen by bilingual experts in the field of early 
childhood education with adequate educational background and related experience. In the context of the present study, the primary language was Arabic so the Arabic version of each item was made available along with the English items. The instrument consisted of 12 items in total in order to gain an understanding of the proficiency level of young children in two domains. The first domain was their receptive language knowledge and included six items (i.e., Touch your nose and chin) and the second was expressive language knowledge which was also consisted of six items (i.e., Listen to what I say and repeat after me "cars go fast").

In addition, a "Parent Interview Questionnaire" tool was the second instrument; it was used in interviews with parent participants about their child's language usage outside the school setting. The Parent Interview tool included seven interview questions on which language was mainly used and adopted by their children (i.e., Which language does your child use most frequently with sibling(s) while communicating with them?). Finally, ademographic survey was attached to these two main instruments.

\subsection{Data collection}

The researcher contacted the CCC administration, discussed the scope of the study, and obtained the cooperation of the CCC staff in reaching the parents of KG2 students prior to sending the parents the informed consent letter and the time schedule in which to submit information for the study. The parents were also asked to state their availability and willingness to participate and provide their consent for their children. After receiving parent responses, the part of the study involving children was administered. In this phase the children were taken to a one-on-one session and asked to respond to all 12 survey items both in English and Arabic. The items were given to the children in random order. In each case, the child was expected to answer in the language in which the item was provided to them. Eleven students participated in this phase. Afterward, the parents of these young children attended interviews and were given the second study instrument. Eleven parents answered the interview questions. All interviews were conducted at the CCC. Triangulation procedures were used following the interviews to handle any validity issues. All interviews were conducted in Arabic. All data were kept on a secure password-protected computer.

\subsection{Data analysis}

Descriptive statistics and qualitative methods were used to analyze the data gathered from students and their parents. First, descriptive analysis of the participants' demographical characteristics was completed. Second, the children's responses to the first instrument were analyzed using the Statistical Package for the Social Sciences (SPSS Version 16.0 for Windows). Lastly, the interviews with parents were analyzed using qualitative techniques. However, the responses from parents were transferred into an exhaustive answer using a triangulation method in order to have a clear answer from them about the language their children used in various daily-life contexts; these answers were analyzed via descriptive statistics.

\section{Findings and Discussion}

Looking first at the demographic characteristics of student participants, the four dimensions were age (ranged between 62 months and 72 months, with an average of 66.8 months); gender (nine girls [82\%] and two boys [18\%]); nationality (Omani was the majority [nine for $82 \%]$, followed by one Jordanian [9\%], and one Iraqi [9\%]); and primary language (Arabic).

In the case of parent participants, age, gender, educational level, and employment status were the factors of interest. First, their ages ranged from 28 to 42 years (average $=36$ ). Second, men and women were almost equally represented-six (55\%) were females and the rest (45\%) were males. Third, with regard to educatin level, four (36\%) had a doctorate, three (27\%) had a master's, three (27\%) had a bachelor's degree, and one had a diploma (9\%). Lastly, all parent participants were employed full-time. Table 1 offers demographic information on participants. 
Table 1. Demographic Characteristics of Participants

\begin{tabular}{|c|c|c|c|c|}
\hline & & & Percentage & Range \\
\hline \multirow{3}{*}{ Students } & Average Age & 66.8 months & & $66-72$ months \\
\hline & Gender & $\begin{array}{l}9 \text { female } \\
2 \text { male }\end{array}$ & $\begin{array}{l}82 \% \\
18 \%\end{array}$ & \\
\hline & Nationality & $\begin{array}{l}9 \text { Omani } \\
1 \text { Iraqi } \\
1 \text { Jordanian }\end{array}$ & $\begin{array}{c}82 \% \\
9 \% \\
9 \%\end{array}$ & \\
\hline \multirow{4}{*}{ Parents } & Average Age & 36 & & $28-42$ years \\
\hline & Gender & $\begin{array}{l}6 \text { females } \\
5 \text { males }\end{array}$ & $\begin{array}{l}55 \% \\
45 \%\end{array}$ & \\
\hline & Education Level & $\begin{array}{l}4 \text { doctorate } \\
3 \text { master } \\
3 \text { bachelor } \\
1 \text { diploma }\end{array}$ & $\begin{array}{c}36 \% \\
27 \% \\
27 \% \\
9 \%\end{array}$ & \\
\hline & Employment Status & 11 Full time & $100 \%$ & \\
\hline
\end{tabular}

The results yielded important information. First, children's average correct answer for Receptive Primary Language items was six over six. The average correct response rate for Expressive Primary Language, Receptive English Language, and Expressive English Language was calculated as 5.8, 5.7, and 5.1, respectively. Table 2 depicts the average correct response rate for each item.

Table 2. Average Correct Response for Each Instrument Domains

\begin{tabular}{|lcc|}
\hline Domain & Arabic (L1) & English (L2) \\
\hline Receptive & 6.0 & 5.7 \\
Expressive & 5.8 & 5.1 \\
\hline
\end{tabular}

Second, the interview results showed the language that children use most outside the educational setting. Table 3 contains information on their language preference in various contexts based on their parents' reports.

Table 3. Language Most Frequently Used by Children in Different Contexts as Reported by Parents

\begin{tabular}{lcc}
\hline Context & Arabic (L1) & English (L2) \\
\hline Communicating with sibling(s) & $1(9 \%)$ & $10(91 \%)$ \\
Playing with friend(s) & $1(9 \%)$ & $10(91 \%)$ \\
Expressing wants and needs & $1(9 \%)$ & $10(91 \%)$ \\
Naming familiar objects, foods, parts of body & $4(36 \%)$ & $7(64 \%)$ \\
Language of the tv programs s/he most frequently enjoys & $5(45 \%)$ & $6(55 \%)$ \\
Language of the stories s/he most frequently requests & $6(55 \%)$ & $5(45 \%)$ \\
While carrying on a conversation with adults & $1(9 \%)$ & $10(91 \%)$ \\
\hline
\end{tabular}

The results indicated that all children enrolled in the KG2 class at CCC were equipped with a competent level of both English and their primary language, suggesting that the bilingual education provided to them had been successful in terms of children's language knowledge and skills. Both expressive and receptive language competencies were at a high level, which showed the children's level of comfort in both languages. But, these children were found to be less competent in Expressive knowledge of English language than the other domains although there was no significant gap. This level can be tolerated since English Language is a"foreign" language to these children-they have less opportunity to use it outside the school. However, in line with this finding, the interview results showed that the children predominantly 
used their primary language in various settings and contexts with different people around them outside the school, especially when communicating with their siblings and/or peers, carrying on a conversation with adults, and expressing their wants and needs. On the other hand, this research study found that most children enjoyed the television programs in English, not in their primary language. Finally, nearly half of the participating young children most frequently requested stories in English rather than their primary language; a significant number were more familiar with the English names of objects, food, and parts of body. These results show that children have made the English language a part of their life; they gained this English language knowledge through their bilingual education in their early years at CCC; and this kind of a program did not have any adverse effect (fewer competencies) on their primary language knowledge and skills. This finding was consistent with those offered in the literature (e.g., Bae, 2007; Dastghaian \& Rostami, 2013). Thus the results showed the success of the bilingual program at CCC.

Although this research yielded significant results, it was limited in terms of number of participants, ages of students, and context. Therefore, future research should be conducted on the language proficiencies of young children enrolled in bilingual programs at different grade levels, in different contexts such as private schools, and with more participants in order to gain a more holistic picture of the phenomenon. Moreover, since the CCC is located on the SQU campus, the participating parents were highly educated. Therefore, more research should be done with children of parents from diverse educational and employment backgrounds. In addition, teachers and parents should be trained and encouraged to promote and improve the Expressive English Language proficiencies of young children. Administrators should work to create training sessions for both teachers and parents in this regard. Lastly, policy makers and other related stakeholders in Oman may use the CCC's bilingual education program as a model for other schools by extending the usage of its curriculum to other schools and providing material help for other early bilingual education programs.

\section{Conclusion}

In conclusion, the children enrolled at CCC and receiving bilingual education in their early years of life benefit from this program in terms of language development-they were found to be highly proficient in both expressive and receptive modes in both English and Primary languages. Thus this type of program should be promoted and extended throughout the region in order to equip young children with two or more languages and raise them as bilingual citizens.

\section{References}

Adesope, O. O., Lavin, T., Thompson, T., \& Ungerleider, C. (2010). A systematic review and meta-analysis of the cognitive correlates of bilingualism. Review of Educational Research, 80, 207-245.

Al-busaidi, K. A. (1995). English in the labour market in multilingual Oman with special reference to Omani employees. Unpublished doctoral dissertation, University of Exeter, England.

Al-issa, A. S. M. (2006). The cultural \& economic politics of ELT in the Sultanate of Oman. Asia EFL Journal, 8(1). Retrieved from http://www.asian-efl-journal.com

Al-issa, A. S. M. , \& Al-bulushi, A. H. (2012). English language teaching reform in sultanate of Oman: The case of theory and practice disparity. Educational Research for Policy and Practice, 11(2), 141-176. doi: 10.1007/s10671-011-9110-0

Al-jardani, K. S. S. (2012). English language curriculum evaluation in Oman. International Journal of English Linguistics, 2(5), 40-44. doi:10.5539/ijel.v2n5p40

Andersson, T. (1974). Bilingual education and early childhood. Hispania, 57(1), 77-78. Retreived from http://www.jstor.org/stable/339444

Bae, J. (2007). Development of English skills need not suffer as a result of immersion: Grades 1 and 2 writing assessment in a Korean/English two-way immersion program. Language Learning, 57(2), 299-332.

Barac, R., \& Bialystok, E. (2011). Cognitive development and bilingual children. Language Teaching, 44(1), 36-54. doi: $10.1017 /$ S0261444810000339

Bialystok, E., Craik, F. I. M., Green, D. W., \& Gollan, T. H. (2009). Bilingual minds. Psychological Science in the Public Interest, 10(3), 89-129. doi: 10.1177/1529100610387084

Boyson, B. A., Semmer, M., Thompson, L. E., Rosenbusch M. H. (2013). Does beginning foreign language in kindergarten make a difference? Results of one district's study. Foreign Language Annals, 46(2), 246-263. doi: 10.1111/flan.12023

Bronfenbrenner, U. (1979. The ecology of human development: Experiments by nature and design. Cambridge, MA: Harvard University Press.

Comeau, L., Genesee, F., \& Mendelson, M. (2010). A comparison of bilingual and monolingual children's conversational repairs. First Language, 30, 354-374. doi: 10.1177/0142723710370530

Dastgahian, E. S., \& Rostami, H. (2013). Early bilingual acquisition, A case study in Iran. International Journal of English Linguistics. 3(6), 97-112. doi:10.5539/ijel.v3n6p97

Dreifus, C. (2011, May 30). The bilingual advantage: Interview with Ellen Bialystok. The New York Times. Retrieved from http://www.nytimes.com/2011/05/31/science/31conversation.html?_r=1 
Du, L. (2010). Initial bilingual development: One language or two? Asian Social Science, 6(5), 132-139. Retrieved from http:// www.ccsenet.org/ass

Francis, D., Lesaux, N., \& August, D. (2006). Language of instruction. In D. August \& T. Shanahan (Eds.),

Developing literacy in second language learners: Report of the national literacy panel on language-minority children and youth (pp. 365-414). Mahwah, NJ: Erlbaum.

Gilakjani, A. P., \& Ahmadi, M. R. (2011). Why is pronunciation so difficult to learn? English Language Teaching, 4(3), 74-83. doi:10.5539/elt.v4n3p74

Habeeb, K. (2013). Teachers' perceptions toward implementing English as a foreign language at kindergarten: What can we learn from the case of Kuwaiti kindergarten teachers? (Doctoral dissertation). Retrieved from. ProQuest Dissertations and Theses database. (1424829567)

Hammer, C. S., Komaroff, E., Rodriguez, B. L., Lopez, L. M., Scarpino, S. E., \& Goldstein, B. (2012). Predicting Spanish-English bilingual children's language abilities. Journal of Speech, Language, and Hearing Research, 55, 1251-1264. doi: 10.1044/10924388(2012/11-0016)

Hidaka, S., Shibata, H., Kurihara, M., Tanaka, A., Konno, A., Maruyama, S., Gyoba, J., Hagiwara, H., \& Koizumi, M. (2012). Effect of second language exposure on brain activity for language processing among preschoolers. Neuroscience Research, 73, 73-79. doi:10.1016/j.neures.2012.02.004

Ho, Y. (2009). The perception and production of American English front vowels by EFL learners in Taiwan: The influence of first anguage and proficiency levels. (Doctoral dissertation). Retrieved from ProQuest Dissertations and Theses database. (304911697)

Hornberger, N. H. (1988). Bilingual education and language maintenance: A southern Peruvian Quechua case. Dortrecht, Holland: Foris.

Hussien, A. M. (2014a). The effect of learning English (L2) on learning of Arabic literacy (L1) in the primary school. International Education Studies, 7(3), 88-98. doi:10.5539/ies.v7n3p88

Hussien, A. M. (2014b). The indicating factors of oral reading fluency of monolingual and bilingual children in Egypt. International Education Studies, 7(2), 75-90. doi: 10.5539/ies.v7n2p75

Jared, D., Poh, R. P. Y., \& Paivio, A. (2013). L1 and L2 picture naming in Mandarin-English bilinguals: A test of bilingual dual coding theory. Bilingualism: Language and Cognition, 16(2), 383-396, doi:10.1017/S1366728912000685

Kan, F. K. (2014). Novel word retention in sequential children. Journal of Child Language. 41, 416-438. doi: 10.1017/S0305000912000761

Keysar, B., Hayakawa, S. L., \& An, S. (2011). The foreign-language effect: Thinking in a foreign tongue reduces decision biases. Psychological Science, 23, 661-668. doi:10.1177/0956797611432178

Klassert, A., Gagarina, N., \& Kauschke, C. (2014). Object and action naming in Russian- and German-speaking monolingual and bilingual children. Bilingualism: Language and Cognition, 17(1), 73-78. doi: 10.1017/S1366728913000096

Lacina, J., Levine, L. N., \& Patience, S. (2010). Learning a second language: Program models in Texas, Florida, and the United Arab Emirates. Childhood Education, 87, 106-112.

Larson-Hall, J. (2008). Weighing the benefits of studying a foreign language at a younger starting age in a minimal input situation. Second Language Research, 24(1), 35-63. doi: 10.1177/0267658307082981

Leikin, M. (2013). The effect of bilingualism on creativity: Developmental and educational perspectives. The International Journal of Bilingualism, 17, 431-447. doi: 10.1177/1367006912438300

Lengyel, D. (2012). Early childhood education in multilingual settings. In Z. Bakerman (Ed.), International handbook of migration, minorities, and education (pp. 169-185). doi: 10.1007/978-94-007-1466-3

Lin, L., \& Johnson, C. J. (2010). Phonological patterns in Mandarin-English bilingual children. Clinical Linguistics \& Phonetics, 24, 369386. doi: $10.3109 / 02699200903532482$

Lopez, M. G., \& Tashakkori, A. (2004). Effects of a two-way bilingual program on the literacy development of students in kindergarten and first grade. Bilingual Research Journal, 28, 19-34. Retrieved from http://www.tandfonline.com/loi/ubrj20\#.U8Qw40Dp-Hw

Marian, V., Shook, A., \& Schroeder, S. R. (2013). Bilingual Two-Way Immersion Programs Benefit Academic Achievement. Bilingual Research Journal, 36, 167-186. doi: 10.1080/15235882.2013.818075

National Center for Statistics and Information (2010). General census of population, housing \& establishments 2010. Retrieved from http://www.ncsi.gov.om/NCSI_website/documents/Census_2010.pdf

Nikolov, M. (2009). Studies on Language Acquisition: The Age Factor and Early Language Learning. Berlin, Germany: Mouton de Gruyter.

Nikolov, M., Csapo, B. (2010). The relationship between reading skills in early English as a foreign language and Hungarian as a first language. International Journal of Bilingualism, 14, 315-329. doi:10.1177/1367006910367854

Oman Cultural Office (n.d.). Education in Oman. Retrieved from http://www.omani.info/education.htm

Paradis, J., Genesee, F., \& Crago, M. (2011). Dual language development and disorders: A handbook on bilingualism \& second language learning. Baltimore, MD: Paul $\mathrm{H}$. Brookes Publishing.

Paradis, J., \& Kirova, A. (2014). English second-language learners in preschool: Profile effects in their English abilities and the role of home language environment. International Journal of Behavioral Development, 38, 342-349. doi: 10.1177/0165025414530630

Pardington, S. (2007, Apr 22). Youngsters go bilingual. The Oregonian Retrieved from http://www.oregonlive.com/oregonian/

Piaget, J. (1959). The language and thought of the child. New York, NY: Routledge Classics.

Piske, T., Mackay, I. R. A., \& Flege, J. E. (2001). Factors affecting degree of foreign accent in an L2: A review. Journal of Phonetics, 29, 191-215. doi: 10.006/jpho.2001.0134 
Poulin-Dubois, D., Blaye, A., Coutya, J., \& Bialystok, E. (2011). The effects of bilingualism on toddlers' executive functioning. Journal of Experimental Child Psychology, 108, 567-579.

Reder, F., Marec-Breton, N, Gombert, J., \& Demont, E. (2013). Second-language learners' advantage in metalinguistic awareness: A question of languages' characteristics. British Journal of Educational Psychology, 83, 686-702. doi: 10.1111/bjep.12003

Sevinc, M., \& Onkol, F. L. (2009). Language processing skills of 5-6 years old Turkish children attending monolingual and bilingual preschool education. Procedia Social and Behavioral Sciences, 1, 1378-1383. doi: 10.1016/j.sbspro.2009.01.243

Sturke, B. R. (2003). Learning in two languages: Assessing a dual language bilingual kindergarten program (Doctoral dissertation). Retrieved from ProQuest Dissertations and Theses database. (305235223)

Sun, B., Zhou, H., \& Zhu, B. (2013). Effects of English phonological awareness training on Chinese child EFL learners' literacy development. Canadian Social Science, 9(1), 56-64. doi: 10.3968/j.css.1923669720130901.1049

UNICEF (2008). Education statistics: Oman. Retreived from http://www.childinfo.org/files/MENA_Oman.pdf

Unsworth, S. (2013). Current Issues in Multilingual First Language Acquisition. Annual Review of Applied Linguistics, 33, 21-50. doi: 10.1017/S0267190513000044

Vygotsky, L. S. (1978). Mind in society: The development of higher psychological processes. Cambridge, MA: Harvard University Press.

Werker, J. (2012). Perceptual foundations of bilingual acquisition in infancy. Annals of the New Yoork Academy of the Sciences, 1251, 50-61. doi: 10.1111/j.1749-6632.2012.06484.x

Yang, S., Yang, H., \& Lust, B. (2011). Early childhood bilingualism leads to advances in executive attention: Dissociating culture and language. Bilingualism: Language and Cognition, 3, 412-422. doi: 10.1017/S1366728910000611

Yeung, S. S., \& Chan, C. K. K. (2012). Phonological awareness and oral language proficiency in learning to read English among Chinese kindergarten children in Hong Kong. British Journal of Educational Psychology, 83, 550-568. doi: 10.1111/j.20448279.2012.02082.x

Zelasko, N., \& Antunez, B. (2000). If your child learns in two languages. Retrieved from http://www.ncela.gwu.edu/files/uploads/9/ IfYourChild LearnsInTwoLangs_English.pdf

Zhang, L., \& Yan, R. (2012). Impact of immersion teaching on English sociopragmatic awareness of Chinese kindergarten children: $A$ polite study. International Education, 41(2), 33-45. Retrieved from http://trace.tennessee.edu/internationaleducation/vol41/iss2/3 